\title{
The Social and Cultural Characteristics of Shanxi Ancient Drama Costumes
}

\author{
XiaoMing Yang ${ }^{1} \&$ XiangMin $\mathrm{Hu}^{1}$ \\ ${ }^{1}$ College of humanities, Donghua University, Shanghai, China \\ Correspondence: XiaoMing Yang. E-mail: nuczxbyjh@163.com
}

Received: January 1, 2020

Accepted: January 13, 2020

Online Published: February 27, 2020

doi:10.5539/ass.v16n3p43

URL: https://doi.org/10.5539/ass.v16n3p43

\begin{abstract}
The main research subject of this paper is the costume of Shanxi ancient drama, which is used to decorate the role in the form of drama performing art that spread in Ancient Shanxi. Drama costume is a kind of special performance costume which combines decoration, acting and symbolism. It is quite different from the traditional costume in aesthetic and functional aspects. The social and cultural factors that influence the costume of Shanxi ancient drama mainly include the system and rules of Chinese ancient costume, the subtle influence of Buddhist culture and Taoist culture, as well as the profound influence of loyalty culture.
\end{abstract}

Keywords: social and cultural characteristics, dramatic-costums, ancient, Shanxi

Shanxi is located to the west of taihang mountain and the east to the Yellow River. Shanxi is the birthplace of human beings, the cradle of Chinese civilization, and one of the cradles of Chinese dramatic art, known as the cradle of drama. According to statistics, there used to be more than 60 kinds of drama art forms in the ancient history of Shanxi, accounting for more than one sixth of the total drama forms in China.

There were three historical peaks of drama art in the SanJin dynasty. The first peak was from the pre-Qin dynasty to the five dynasties. During this period, Shanxi gave birth to a large number of theatrical performances, which were collectively referred to as song and dance hundreds of operas. Typical artistic performances included miscellaneous operas, music and dance. This period also saw the emergence of rap drama - "canjun"drama. The second peak was in the Song, Liao, Jin and Yuan dynasties, when various kinds of dramas appeared on stage. Typical art performance forms included courtyard books and zaju. The third peak is the Ming and Qing dynasties, almost all the essence of traditional Chinese drama here convergence blend sublimation, and spread throughout the country and even the world, the typical form of artistic performance has a legendary opera and a variety of Bangzi opera.

Theatrical costumes refer to all kinds of costumes specially made according to the needs of theatrical characters. Apart from the decoration, the style, color, pattern and material of the costume also contain rich historical, cultural, artistic, scientific and technological elements. As a special historical mark and cultural symbol, costume inevitably bears a distinct brand of social culture, so does theatrical costume. The social and cultural factors affecting Shanxi ancient theatrical costumes are various, and other areas by limitations of the ancient Chinese clothing system and rules, unconsciously by religious culture (mainly Buddhist culture and Taoism culture), at the same time has also been SanJin culture unique Huang Hegen progenitor culture, secondly the culture, business culture and the profound influence of the frontier fortress culture.

\section{The Influence of Costume Regulation on Drama Costume}

For the function orientation of clothing, all the rulers of Chinese traditional society thought that clothing is the important foundation stone of consolidating state power and the concrete embodiment of maintaining social ethical order. Therefore, the rulers of all dynasties have attached great importance to the management of clothing, which has been upgraded to the will of the state, and gradually formed a set of strict clothing system and management methods. The national costume system originated from the Zhou Dynasty, and these systems were first recorded in ancient books such as Shangshu and Liji. In the later generations, the national costume system has been continuously strengthened and improved, forming a complete, rigorous and orderly costume system, which has the most extensive and far-reaching influence on drama costumes, including the crown costume system, twelve chapter patterns, costume hierarchy system and patchwork patterns, and provisions on folk 
costumes. In order to strengthen the management of drama cultural activities, there was a long-term system of "Le Hu" in Chinese history, which began in the Northern Wei Dynasty and ended in the middle of the Qing Dynasty. Shanxi was the last area to cancel the "Le Hu" system, which had a great influence on the formation and development of ancient drama costumes. Shanxi, as the cradle of Chinese drama culture and the important town of drama art, the central and local rulers of the past dynasties have constantly strengthened their control over Shanxi drama performance. The rise and fall of Shanxi ancient drama and its costumes are closely related to it.

\section{The Influence of Loyalty Culture on Drama Costume}

It is not only a tradition of Shanxi culture, but also a characteristic of Shanxi culture communication to inherit and carry forward the loyalty culture by drama. The reason why loyalty culture is valuable is that loyalty spirit has connotation. In the history of drama development for thousands of years, loyalty plays have always played an important role in the stage of drama, and they are most popular with the public. Therefore, many drama art images and costumes representing loyalty are left behind. The representative of the lofty moral spirit in Chinese civilization. The spirit of loyalty is mainly composed of loyalty and righteousness. As far as loyalty and righteousness in general sense are concerned, loyalty is not simply obedience, nor is righteousness simply following certain rules. Loyalty, moral integrity, "loyalty, respect also, wholeheartedly said loyalty, from the heart voice."Zengzi said, "do you think I'm unfaithful because I'm a schemer? Do you make friends without trust? Are you familiar with passing?"Loyalty is the virtue that people are selfless, consistent and responsible for fulfilling their duties to heaven and earth, truth, faith, duty, country and others. Justice, good and benevolence and righteousness, is the right reason for the world. "The righteous should also respect the capital for the great", "unjust and rich, and I like floating clouds."In history, loyalty has been given more political and cultural connotations, such as loyalty to the emperor and patriotism, loyalty to the country, sacrifice one's life for righteousness and so on. The land of the three Jin Dynasty has been famous for advocating loyalty since ancient times. From a series of idioms, allusions and a series of dramas, novels and other literary works that people have been familiar with so far, it is not difficult to see the profound accumulation and long-standing influence of the social fashion of advocating loyalty in Ancient Shanxi.

\section{The Influence of Buddhist Culture on the Costume of drama}

Buddhism originated in ancient India in the 6th century B.C. and gradually spread to China in the late Western Han Dynasty and the early Eastern Han Dynasty around the 1st century A.D. it began to spread widely in China from the Wei, Jin, southern and Northern Dynasties to the Sui and Tang Dynasties when it reached its peak due to the strong support of the rulers. During this period, Buddhism culture and traditional Chinese culture gradually merged and developed through long-term communication, forming a Chinese national characteristic Chinese Buddhism of color. Buddhism did not first spread in Shanxi Province, but because of its unique geographical environment, historical and cultural traditions and social and political background at that time, Buddhism flourished rapidly after it was spread to Shanxi in the north, and Shanxi also became one of the important bases of Chinese Buddhist culture.

From the Northern Wei Dynasty, the art of music and dance drama serving Buddhism gradually became Chinese and secularized. The Yungang Grottoes in Datong of Shanxi Province, which was built in the early years of the Northern Wei Dynasty, are carved and painted with a large number of Buddhist music and dance stone carvings and frescoes that entertain, praise, support and preach Buddhist principles. Among the twelve grottoes of Yungang Grottoes known as"music Grottoes", the seven body Kabuki lotian and Tiangong Kabuki music niches are the representative works, with prosperous categories and large scale. Looking at the music and dance drama modeling of the whole Yungang Grottoes, it is clearly different from before and after, which reflects the unique features of the integration of Han culture and Buddhist culture in that particular historical period.

\section{The Influence of Taoist Culture on the Costume of Drama}

As the birthplace and important activity area of the prosperity and development of Taoism, Taoism culture in Shanxi has had a great impact on the development of drama. For example, as the key performance content of Chinese drama, the fairy tale has been developing with the development of opera art. The story of crane hair and child face, longevity and Tianqi, feathering and ascending to the immortals has always been one of the themes of Shanxi ancient drama performance. Zhu Quan, the 16th son of Zhu Yuanzhang of Ming Dynasty, who once lived in the northern part of China, in his opera theory Taihe Zhengyin Pu, according to the content of the zaju, the Zaju can be divided into twelve categories, namely, immortality, seclusion, embracing robes, loyal officials and martyrs, filial piety and incorruptibility, scolding and slandering, chasing officials and orphans, cymbal force driving away sticks, wind, flowers, snow, joys and sorrows, fireworks and powder Dai, gods and ghosts. Among 
them, the plays reflecting the immortality and Taoism are listed in the first place, and the following reclusive music and ghosts are actually Taoist contents. The three"together accounted for a quarter of the proportion of the Zaju at that time, which does not include the related themes involved in other plays, so we can see the status and influence of Daohua plays in Zaju". According to the statistics of some scholars, there are 34 kinds of immortal dramas in Yuan Dynasty.

After thousands of years of image accumulation in Han, Wei, Sui, Tang, Song, Yuan, Ming and Qing Dynasty, and the rapid spread and development of Taoism in the folk, those gods in traditional Taoism, such as Sanqing, Baxian, Hehe Erxian, Magu xianshou, door god, Kitchen God and other Taoist figures and patterns of Taoist culture have been established. These images have become the basic model of reflecting Taoist content and character costumes in Shanxi ancient drama and important elements. In Taoist culture, the patterns that have a great influence on drama costumes include Taiji pattern, Bagua pattern, crane pattern, dark eight immortals pattern, sun, moon and stars pattern, etc.

\section{References}

Liao, B. (1989). Cultural relics and folk customs of song and Yuan drama. Beijing: Culture and Art Press.

Institute of Drama Cultural Relics, Shanxi Normal University. (1987). On the cultural relics of drama in song, Jin and Yuan Dynasties. Taiyuan: Shanxi People's Publishing House.

Zhou, X. B. (1984, September). The history of ancient Chinese costume. Beijing: China Drama Press.

Song, J. H. (2003, July). A study on the costume of ancient Chinese drama. Guangdong: Guangdong Higher Education Press.

Tian, Z. Y. C. (2011, July). History of Chinese drama. Beijing: Peking University Press.

\section{Copyrights}

Copyright for this article is retained by the author(s), with first publication rights granted to the journal.

This is an open-access article distributed under the terms and conditions of the Creative Commons Attribution license (http://creativecommons.org/licenses/by/4.0/). 